\title{
Saccharibacillus sacchari gen. nov., sp. nov., isolated from sugar cane
}

Correspondence

Encarna Velázquez evp@usal.es

\author{
Raúl Rivas, ${ }^{1}$ Paula García-Fraile, ${ }^{1}$ José Luis Zurdo-Piñeiro, ${ }^{1}$ \\ Pedro F. Mateos, ${ }^{1}$ Eustoquio Martínez-Molina, ${ }^{1}$ Eulogio J. Bedmar, ${ }^{2}$ \\ Juan Sánchez-Raya ${ }^{2}$ and Encarna Velázquez ${ }^{1}$
${ }^{1}$ Departamento de Microbiología y Genética, Lab 209, Edificio Departamental de Biología Campus Miguel de Unamuno, Universidad de Salamanca, Spain \\ ${ }^{2}$ Estación Experimental del Zaidín, CSIC, Granada, Spain
}

The family 'Paenibacillaceae' currently contains eight genera of Gram-positive, -variable or -negative sporulating bacilli. The description of the most recently described genus of the family, Cohnella (Kämpfer et al., 2006), was based on its phylogenetic relationship with respect to the remaining genera of the family as well as on its polar lipid profile. Some species of this family, mainly belonging to the genus Paenibacillus, have been isolated from the plant rhizosphere, but only Paenibacillus polymyxa has been reported as a plant endophyte (Cho et al., 2006). In the present work, we describe the isolation and identification of a novel bacterium isolated from apoplastic sap of sugar cane (Saccharum officinarum) in Granada (Spain).

For the isolation of strain GR $21^{\mathrm{T}}$, stem pieces were washed with sterile tap water and soaked in $5 \%$ chloramine $\mathrm{T}$ solution for $2 \mathrm{~min}$. After removal of the rind with a sterile

The GenBank/EMBL/DDBJ accession number for the $16 \mathrm{~S}$ rRNA gene sequence of strain GR2 $1^{\top}$ is EU014873.

Electron micrographs of cells of strain GR21 $1^{\top}$, an extended neighbourjoining tree and results of 2D TLC of polar lipids of strain GR2 $1^{\top}$ are available as supplementary material with the online version of this paper. sharp knife, the cylinder of parenchyma tissue was rinsed with $70 \%$ ethanol and flame-sterilized. Apoplastic sap from the internodes was collected by centrifugation according to Dong et al. (1994), and serial dilutions were streaked on tryptone soybean agar (TSA) and incubated at $30{ }^{\circ} \mathrm{C}$ for 7-10 days. After flaming, no contamination was observed when several stem pieces were incubated on TSA plates.

Strain GR2 $1^{\mathrm{T}}$ was grown on nutrient agar for $48 \mathrm{~h}$ at $22{ }^{\circ} \mathrm{C}$ to check for motility by phase-contrast microscopy using the hanging drop method. Gram staining was carried out by the procedure described by Doetsch (1981). The flagellation type was determined by electron microscopy after $48 \mathrm{~h}$ incubation on nutrient agar at $22{ }^{\circ} \mathrm{C}$. Cells were gently suspended in sterile water and then stained with $0.2 \%$ uranyl acetate and examined at $80 \mathrm{kV}$ with a Zeiss EM 209 transmission electron microscope. For scanning microscopy, cells were fixed overnight in phosphate buffer (pH 7.0) which contained $2 \%$ paraformaldehyde and $0.2 \%$ glutaraldehyde, dehydrated through a graded ethanol series, critical-point dried and sputter-coated with gold. 
Samples were observed under a Zeiss DSM 490 electron microscope (Germany). Strain GR $21^{\mathrm{T}}$ was Gram-variable and motile by means of polar and subpolar flagella (Supplementary Fig. S1, available in IJSEM Online). Round, non-ornamented central or subterminal spores are formed in unswollen sporangia. In the genus Paenibacillus, the phylogenetically closest related genus of strain $\mathrm{GR} 21^{\mathrm{T}}$ (see below), the spores are commonly ornamented and are formed in swollen sporangia.

Amplification of the $16 \mathrm{~S} \mathrm{rRNA}$ gene and its sequencing was performed according to the method of Rivas et al. (2007). A nearly complete $16 \mathrm{~S}$ rRNA gene sequence was obtained and compared with those deposited in GenBank using the BLASTN (Altschul et al., 1990) and EzTaxon (Chun et al., 2007) programs. Sequences were aligned using the CLUSTAL_X software (Thompson et al., 1997). Distances were calculated according to Kimura's two-parameter method (Kimura, 1980). Phylogenetic trees were inferred using the neighbour-joining (Saitou \& Nei, 1987) and minimum-evolution (Rzhetsky \& Nei, 1992) methods. Bootstrap analysis was based on 1000 resamplings. The MEGA2 package (Kumar et al., 2001) was used for all analyses. Comparison of the nearly complete $16 \mathrm{~S}$ rRNA gene sequence of strain GR $21^{\mathrm{T}}$ against sequences held in GenBank indicated that the organism is phylogenetically related to members of the family 'Paenibacillaceae', with Paenibacillus as the closest related genus (Fig. 1). According to the results obtained with the EzTaxon program, the most closely related type strains of species of this genus with validly published names were those of Paenibacillus xylanilyticus, $P$. massiliensis, $P$. chitinolyticus and P. sepulcri, with identities ranging from 93.4 to $93.0 \%$. The BLASTN program showed similar results, but this comparison showed that the strain HR1, incorrectly named Paenibacillus xinjiangensis, a name that has already been validly published within the genus Paenibacillus, has $98 \%$ similarity in its $16 \mathrm{~S}$ rRNA gene with respect to strain GR21 ${ }^{\mathrm{T}}$. Although strain HR1 could belong to the new genus described below, it was not included in this work because only its $16 \mathrm{~S}$ rRNA gene sequence is currently known (nevertheless, this sequence was included in Supplementary Fig. S2 to show the phylogenetic location of strain HR1). Fig. 1 shows the phylogenetic tree obtained with the neighbour-joining method (an expanded tree is shown in Supplementary Fig. S2). Similar results were obtained when the sequences were analysed using the minimum-evolution method (not shown). The phylogenetic analysis showed the

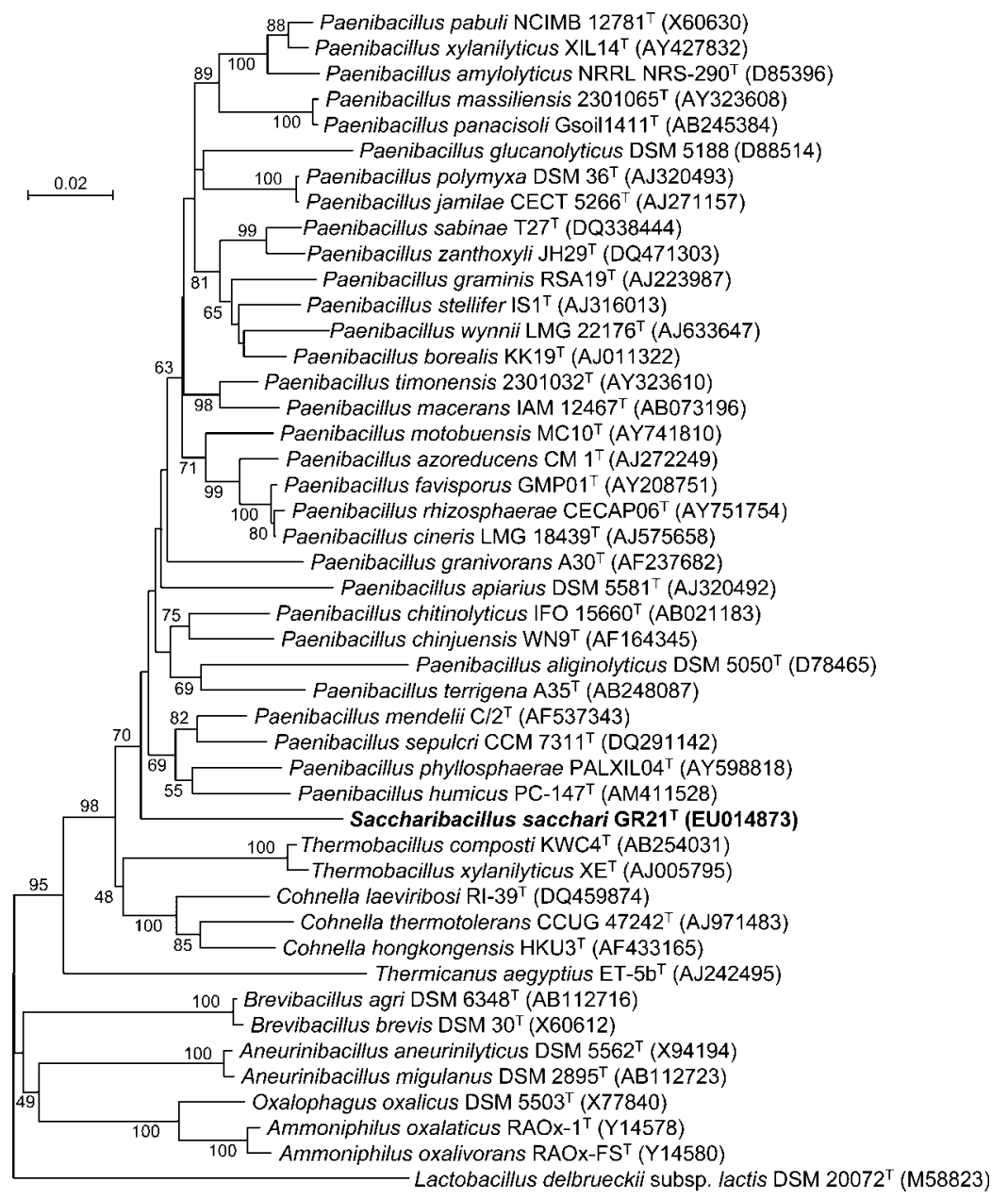

Fig. 1. Comparative sequence analysis of the 16S rRNA gene from strain GR21 ${ }^{\top}$ (Saccharibacillus sacchari gen. nov., sp. nov.) and representative species of related genera from the family 'Paenibacillaceae' using the neighbour-joining method. The significance of each branch is indicated by a bootstrap percentage calculated for 1000 subsets. Bar, 2 substitutions per 100 nucleotide positions. An extended version of this tree is available as Supplementary Fig. S2. 
location of strain GR $21^{\mathrm{T}}$ on an independent branch clearly separated from all genera of the family 'Paenibacillaceae'. This result supports the classification of this strain in a new genus within this family, with the genus Paenibacillus as the closest related genus, the most closely related species of which is P. xylanilyticus, with $93.4 \%$ similarity to the type strain. The genera Thermobacillus and Cohnella were the next most closely related genera, with a maximum of 89.8 and $90.2 \%$ similarity, respectively.

Chemotaxonomic analyses were performed by the Identification Service of the DSMZ according to Tindall (1990) in the case of respiratory quinones and polar lipids and Kämpfer \& Kroppenstedt (1996) in the case of fatty acids. To perform the analysis of peptidoglycan, whole cells of strain GR $21^{\mathrm{T}}$ were hydrolysed with $\mathrm{HCl}$ at $100{ }^{\circ} \mathrm{C}$ for $15 \mathrm{~h}$. The hydrolysates were subjected to TLC on cellulose plates using the solvent system of Rhuland et al. (1955).

As is found in the case of the genus Paenibacillus (Shida et al., 1997), meso-diaminopimelic acid was detected in the peptidoglycan of strain GR $21^{\mathrm{T}}$. No data on peptidoglycan composition have been reported for the remaining genera of the family 'Paenibacillaceae'. MK-7 was the predominant isoprenoid quinone found in strain GR2 $1^{\mathrm{T}}$, and only a small amount of MK-6 was detected (1.5\%). An unidentified menaquinone was also found (2\%). Respiratory quinones have low resolution within the family 'Paenibacillaceae', since MK-7 is the major quinone in most members of the family. The presence of an unidentified quinone may be a differentiating character of the new genus, but this hypothesis should be confirmed when more species of this genus are described.

The major cellular fatty acid of the strain was anteiso- $\mathrm{C}_{15: 0}$ (45.2\%). $\mathrm{C}_{16: 0}$ represented $25.2 \%$, and other fatty acids were present in amounts of less than $10 \%$ (Table 1). Although anteiso- $\mathrm{C}_{15: 0}$ is the dominant cellular fatty acid in all members of the genus Paenibacillus (Shida et al., 1997), the profile of strain GR $21^{\mathrm{T}}$ differs from those of members of the genus Paenibacillus in the amounts of the fatty acids $\mathrm{C}_{14: 0}$ and anteiso- $\mathrm{C}_{17: 0}$. More differences were found in the case of the genus Cohnella (Kämpfer et al., 2006) and particularly in the case of the genus Thermobacillus (Touzel et al., 2000).

Strain GR $21^{\mathrm{T}}$ displayed a lipid profile consisting of diphosphatidylglycerol (DPG), phosphatidylglycerol (PG), an aminophospholipid (PN), two unknown glycolipids (GL1 and GL2) and an unknown phosphoglycolipid (PGL). DPG was the major polar lipid, as is the case for other genera of the family 'Paenibacillaceae' (Kämpfer et al., 2006). PG is also present in those genera that contain glycolipids GL1 or GL2. In strain GR21 ${ }^{\mathrm{T}}$, both unknown glycolipids were present. Strain GR $21^{\mathrm{T}}$ contains PN instead of phosphatidylethanolamine, which is found in other genera of the family 'Paenibacillaceae'. PGL is present in small amounts in strain GR $21^{\mathrm{T}}$ and has not been reported in the other genera of the family 'Paenibacillaceae'. Therefore, the polar lipid profile of strain GR2 $1^{\mathrm{T}}$
Table 1. Fatty acid contents of strain GR21 ${ }^{\top}$ (Saccharibacillus sacchari gen. nov., sp. nov.) and closely related genera of the family 'Paenibacillaceae'

Values are percentages of total fatty acids. Data for reference genera were compiled from Kämpfer et al. (2006) and Touzel et al. (2000) (Paenibacillus), Kämpfer et al. (2006) and Cho et al. (2007) (Cohnella) and Touzel et al. (2000) and Watanabe et al. (2007) (Thermobacillus). ND, Not detected; NR, not reported.

\begin{tabular}{|lcccc|}
\hline Fatty acid & $\begin{array}{c}\text { Strain } \\
\text { GR21 }\end{array}$ & Paenibacillus Cohnella & $\begin{array}{c}\text { Thermo- } \\
\text { bacillus }\end{array}$ \\
\hline $\begin{array}{l}\text { Saturated acids } \\
\text { Straight-chain }\end{array}$ & & & & \\
$\mathrm{C}_{12: 0}$ & 0.7 & $\mathrm{NR}$ & $\mathrm{NR}$ & $\mathrm{NR}$ \\
$\mathrm{C}_{14: 0}$ & 7.6 & $1.2-3.3$ & $1-5$ & $0.5-1.2$ \\
$\mathrm{C}_{15: 0}$ & $\mathrm{ND}$ & $0.6-6.7$ & $1.4-8$ & $1.8-4.2$ \\
$\mathrm{C}_{16: 0}$ & 25.2 & $8.1-28.0$ & $6.6-25.3$ & $2.9-21.4$ \\
$\mathrm{C}_{17: 0}$ & $\mathrm{ND}$ & $\mathrm{NR}$ & 1.2 & $0.3-0.9$ \\
$\mathrm{C}_{18: 0}$ & $\mathrm{ND}$ & $\mathrm{NR}$ & $\mathrm{NR}$ & 0.7 \\
iso-branched & & & & \\
$\mathrm{C}_{14: 0}$ & 7.7 & $0.6-7.2$ & $2.1-3.9$ & $1-4.4$ \\
$\mathrm{C}_{15: 0}$ & 3.0 & $1.0-12.0$ & $3.2-11.7$ & $0.9-4.6$ \\
$\mathrm{C}_{16: 0}$ & 6.3 & $0.5-6.0$ & $11.9-45.5$ & $39.0-48.0$ \\
$\mathrm{C}_{17: 0}$ & 0.8 & $1-6.9$ & 2.8 & $1.4-1.8$ \\
$\mathrm{C}_{18: 0}$ & $\mathrm{ND}$ & $\mathrm{NR}$ & $\mathrm{NR}$ & 1.1 \\
anteiso-branched & & & & \\
$\mathrm{C}_{13: 0}$ & 0.2 & $\mathrm{NR}$ & 0.8 & 0.5 \\
$\mathrm{C}_{15: 0}$ & 45.2 & $28.2-80.0$ & $22.0-31.2$ & $8.7-33.3$ \\
$\mathrm{C}_{17: 0}$ & 2.3 & $6.0-7.0$ & $2.6-6.7$ & $7.4-12.4$ \\
Unsaturated acids & & & & \\
anteiso-C $_{17: 1}$ & $\mathrm{ND}$ & $\mathrm{NR}$ & $1.1-1.9$ & $\mathrm{NR}$ \\
$\mathrm{C}_{16: 1} \omega 11 c$ & 0.8 & $\mathrm{NR}$ & 0.9 & $\mathrm{NR}$ \\
$\mathrm{C}_{17: 1} \omega 6 c$ & $\mathrm{ND}$ & $\mathrm{NR}$ & 1 & $\mathrm{NR}$ \\
$\mathrm{C}_{18: 1} \omega 7 c$ & $\mathrm{ND}$ & $\mathrm{NR}$ & 4 & $\mathrm{NR}$ \\
& & & & \\
\hline
\end{tabular}

(Supplementary Fig. S3) is clearly different from those of members of other genera of the family 'Paenibacillaceae' reported by Kämpfer et al. (2006), supporting the affiliation of strain GR $21^{\mathrm{T}}$ to a new genus within the family 'Paenibacillaceae'.

DNA for determination of the base composition was prepared according to Chun \& Goodfellow (1995). The $\mathrm{G}+\mathrm{C}$ content of the DNA was determined using the thermal denaturation method (Mandel \& Marmur, 1968). The $\mathrm{G}+\mathrm{C}$ content of strain $\mathrm{GR} 21^{\mathrm{T}}$ was $57.8 \mathrm{~mol} \%$.

The phenotypic characterization was performed according to the standard methods described by Claus \& Berkeley (1986) and Logan \& Berkeley (1984) and by using the API 20NE and API 20E systems (bioMérieux) according to the manufacturer's instructions. Amylases and cellulases were analysed as described previously (Rivas et al., 2003). Growth was determined at temperatures ranging from 4 to $45{ }^{\circ} \mathrm{C}$ in YED medium $(0.5 \%$ yeast extract, $0.7 \%$ glucose and $2 \%$ agar). Growth at pH 5.7 and 6.8 was tested as described by Claus \& Berkeley (1986), growth at $\mathrm{pH} 7.0$ 8.0 was tested in YED medium containing $100 \mathrm{mM}$ 
$\mathrm{Na}_{2} \mathrm{HPO}_{4} / \mathrm{NaH}_{2} \mathrm{PO}_{4}$ and growth at $\mathrm{pH} 9.0-10.0$ was tested in YED medium containing $100 \mathrm{mM} \mathrm{NaHCO} / \mathrm{Na}_{2} \mathrm{CO}_{3}$. The phenotypic characteristics are given in the genus and species descriptions. Differential characteristics with respect to the closest related genera are shown in Table 2 .

On the basis of phylogenetic, chemotaxonomic and phenotypic data, we propose that isolate $\mathrm{GR} 21^{\mathrm{T}}$ belongs to a new genus and species within the family 'Paenibacillaceae', for which the name Saccharibacillus sacchari gen. nov., sp. nov. is proposed.

\section{Description of Saccharibacillus gen. nov.}

Saccharibacillus (Sac.cha.ri.ba.cil'lus. N.L. n. Saccharum a botanical genus name; L. masc. n. bacillus a small staff or rod; N.L. masc. n. Saccharibacillus a small rod isolated from Saccharum officinarum, sugar cane).

Gram-variable, motile, rod-shaped bacteria. Round, nonornamented spores are formed in unswollen sporangia. Catalase- and oxidase-negative. Main menaquinone is MK7. Predominant lipids are diphosphatidylglycerol, phosphatidylglycerol and an unknown aminophospholipid. In addition, two unknown glycolipids and an unknown phosphoglycolipid are present. The major fatty acids are anteiso- $\mathrm{C}_{15: 0}$ and $\mathrm{C}_{16: 0}$. The type species is Saccharibacillus sacchari.

\section{Description of Saccharibacillus sacchari sp. nov.}

Saccharibacillus sacchari (sac'cha.ri. L. gen. n. sacchari of sugar, referring to the isolation source of the type strain, inner tissues of sugar cane).

Cells are $0.8-1 \mu \mathrm{m}$ wide and 3-4 $\mu \mathrm{m}$ long. Motile by means of polar or subpolar flagella. Spores are formed in a central or subterminal position in cells. Aerobic or facultatively anaerobic and chemo-organotrophic. Colonies on TSA are circular with irregular borders, pale pink, not mucoid, opaque and usually $1-2 \mathrm{~mm}$ in diameter within $48 \mathrm{~h}$ at $28{ }^{\circ} \mathrm{C}$. Growth occurs at $8-40{ }^{\circ} \mathrm{C}$; optimal growth at $28{ }^{\circ} \mathrm{C}$ and $\mathrm{pH}$ 7. Acetoin is produced. Grows in the presence of $2 \%$ $\mathrm{NaCl}$. Nitrate is reduced to nitrite. Cellulases, xylanases and $\beta$ galactosidase are produced actively, but amylases, gelatinase, caseinase, arginine dihydrolase, indole, lysine decarboxylase, ornithine decarboxylase, urease, tryptophan deaminase, phenylalanine deaminase and hydrogen sulfide are not produced. Aesculin is hydrolysed. Acid but not gas is produced from D-glucose. D-Glucose, mannose, maltose, mannitol and gluconate are used as carbon sources.

Table 2. Differential characteristics between strain GR21 ${ }^{\top}$ (Saccharibacillus sacchari gen. nov., sp. nov.) and phylogenetically related genera from the family 'Paenibacillaceae'

Data for Paenibacillus were compiled in this study from those recorded for the closest species to strain GR21 $1^{\mathrm{T}}, P . x y l a n i l y t i c u s, P$. sepulcri, $P$. massiliensis and P. chitinolyticus, which are basically in agreement with those reported for the genus Paenibacillus by Shida et al. (1997). Data for Cohnella were taken from Teng et al. (2003), Kämpfer et al. (2006) and Cho et al. (2007) and data for Thermobacillus were taken from Touzel et al. (2000) and Watanabe et al. (2007). +, Positive; -, negative; v, variable; ND, no data available.

\begin{tabular}{|c|c|c|c|c|}
\hline Characteristic & Saccharibacillus & Paenibacillus & Cohnella & Thermobacillus \\
\hline Sporangia & Not swollen & Swollen & $\mathrm{ND}$ & Swollen $^{a}$ \\
\hline Catalase & - & + & $\mathrm{V}$ & + \\
\hline Oxidase & - & $\mathrm{v}$ & $\mathrm{V}$ & $\mathrm{V}$ \\
\hline Nitrate reduction to nitrite & + & $\mathrm{V}$ & $+{ }^{b}$ & $-{ }^{a}$ \\
\hline Amylase & - & $\mathrm{v}$ & ND & + \\
\hline Acetoin production & + & $\mathrm{V}$ & $-{ }^{b}$ & $\mathrm{ND}$ \\
\hline Growth at pH 5.7 & + & - & $+{ }^{c}$ & $\mathrm{~V}$ \\
\hline Growth at $50{ }^{\circ} \mathrm{C}$ & - & - & + & + \\
\hline Growth in presence of $2 \% \mathrm{NaCl}$ & + & + & $-^{c}$ & + \\
\hline Mannitol & - & $\mathrm{v}$ & $\mathrm{v}$ & ND \\
\hline Major polar lipids & DPG, PG & DPG, PE & $\mathrm{DPG}, \mathrm{PG}, \mathrm{PE}$ & ND \\
\hline Major fatty acid(s) (>25\%) & ai- $C_{15: 0}, C_{16: 0}$ & ai- $\mathrm{C}_{15: 0}$ & ai- $C_{15: 0}, \mathrm{i}-\mathrm{C}_{16: 0}, \mathrm{C}_{16: 0}$ & $\mathrm{i}-\mathrm{C}_{16: 0}$, ai- $\mathrm{C}_{15: 0}$ \\
\hline
\end{tabular}

${ }^{\star}$ Data available for the following species only: $a$, Thermobacillus xylanilyticus; $b$, Cohnella hongkongensis; $c$, Cohnella laeviribosi; $d$, Thermobacillus composti. 
Assimilation of L-arabinose, D-xylose, $\mathrm{N}$-acetylglucosamine, caprate, adipate, malate, citrate and phenylacetate is negative. The DNA G + C content of the type strain is $57.8 \mathrm{~mol} \%$.

The type strain, GR $21^{\mathrm{T}}\left(=\mathrm{LMG} 24085^{\mathrm{T}}=\mathrm{DSM} 19268^{\mathrm{T}}\right)$, was isolated from inner tissues of Saccharum officinarum in Granada (Spain).

\section{Acknowledgements}

This work was supported by the JCyL (regional Spanish Government). Financial support was also obtained from the Ministerio de Educación y Ciencia grant CGL2006-06870/BOS with FEDER cofinance. We are grateful to the DSMZ staff for chemotaxonomic analyses.

\section{References}

Altschul, S. F., Gish, W., Miller, W., Myers, E. W. \& Lipman, D. J. (1990). Basic local alignment search tool. J Mol Biol 215, 403-410.

Cho, K. M., Hong, S. Y., Lee, S. M., Kim, Y. H., Kahng, G. G., Kim, H. \& Yun, H. D. (2006). A cel44C-man26A gene of endophytic Paenibacillus polymyxa GS01 has multi-glycosyl hydrolases in two catalytic domains. Appl Microbiol Biotechnol 73, 618-630.

Cho, E. A., Lee, J. S., Lee, K. C., Jung, H. C., Pan, J. G. \& Pyun, Y. R. (2007). Cohnella laeviribosi sp. nov., isolated from a volcanic pond. Int J Syst Evol Microbiol 57, 2902-2907.

Chun, J. \& Goodfellow, M. (1995). A phylogenetic analysis of the genus Nocardia with $16 \mathrm{~S}$ rRNA sequences. Int J Syst Bacteriol 45, 240-245.

Chun, J., Lee, J. H., Jung, Y. J., Kim, M., Kim, S., Kim, B. K. \& Lim, Y. W. (2007). EzTaxon: a web-based tool for the identification of prokaryotes based on $16 \mathrm{~S}$ ribosomal RNA gene sequences. Int J Syst Evol Microbiol 57, 2259-2261.

Claus, D. \& Berkeley, R. C. W. (1986). Genus Bacillus Cohn 1872, $174^{\mathrm{AL}}$. In Bergey's Manual of Systematic Bacteriology, vol. 2, pp. 11051139. Edited by P. H. A. Sneath, N. S. Mair, M. E. Sharpe \& J. G. Holt. Baltimore: Williams \& Wilkins.

Doetsch, R. N. (1981). Determinative methods of light microscopy. In Manual of Methods for General Bacteriology, pp. 21-33. Edited by P. Gerhardt, R. G. E. Murray, R. N. Costilow, E. W. Nester, W. A. Wood, N. R. Krieg \& G. B. Phillips. Washington, DC: American Society for Microbiology.

Dong, Z., Canny, M. J., McCully, M. E., Roboredo, M. R., Fernandez Cabadilla, C., Ortega, E. \& Rodés, R. (1994). A nitrogen-fixing endophyte of sugarcane stems. A new role for the apoplast. Plant Physiol 105, 1139-1147.

Kämpfer, P. \& Kroppenstedt, R. M. (1996). Numerical analysis of fatty acid patterns of coryneform bacteria and related taxa. Can J Microbiol 42, 989-1005.

Kämpfer, P., Rosselló-Mora, R., Falsen, E., Busse, H.-J. \& Tindall, B. J. (2006). Cohnella thermotolerans gen. nov., sp. nov., and classification of 'Paenibacillus hongkongensis' as Cohnella hongkongensis sp. nov. Int J Syst Evol Microbiol 56, 781-786.

Kimura, M. (1980). A simple method for estimating evolutionary rates of base substitutions through comparative studies of nucleotide sequences. J Mol Evol 16, 111-120.

Kumar, S., Tamura, K., Jakobsen, I.-B. \& Nei, M. (2001). Molecular evolutionary genetics analysis software. Tempe, AZ: Arizona State University.

Logan, N. A. \& Berkeley, R. C. W. (1984). Identification of Bacillus strains using the API system. J Gen Microbiol 130, 1871-1882.

Mandel, M. \& Marmur, J. (1968). Use of ultraviolet absorbance temperature profile for determining the guanine plus cytosine content of DNA. Methods Enzymol 12B, 195-206.

Rhuland, L. E., Work, E., Denman, R. F. \& Hoare, D. S. (1955). The behaviour of the isomers of $\alpha, \varepsilon$-diaminopimelic acid on paper chromatograms. J Am Chem Soc 77, 4844-4846.

Rivas, R., Sánchez, M., Trujillo, M. E., Zurdo-Piñeiro, J. L., Mateos, P. F., Martínez-Molina, E. \& Velázquez, E. (2003). Xylanimonas cellulosilytica gen. nov., sp. nov., a xylanolytic bacterium isolated from a decayed tree (Ulmus nigra). Int J Syst Evol Microbiol 53, 99-103.

Rivas, R., Garcia-Fraile, P., Mateos, P. F., Martínez-Molina, E. \& Velázquez, E. (2007). Characterization of xylanolytic bacteria present in the bract phyllosphere of the date palm Phoenix dactylifera. Lett Appl Microbiol 44, 181-187.

Rzhetsky, A. \& Nei, M. (1992). A simple method for estimating and testing minimum-evolution trees. Mol Biol Evol 9, 945-967.

Saitou, N. \& Nei, M. (1987). The neighbor-joining method: a new method for reconstructing phylogenetic trees. Mol Biol Evol 4, 406-425.

Shida, O., Takagi, H., Kadowaki, K., Nakamura, L. K. \& Komagata, K. (1997). Transfer of Bacillus alginolyticus, Bacillus chondroitinus, Bacillus curdlanolyticus, Bacillus glucanolyticus, Bacillus kobensis, and Bacillus thiaminolyticus to the genus Paenibacillus and emended description of the genus Paenibacillus. Int J Syst Bacteriol 47, 289-298.

Teng, J. L., Woo, P. C., Leung, K. W., Lau, S. K., Wong, M. K. \& Yuen, K. Y. (2003). Pseudobacteraemia in a patient with neutropenic fever caused by a novel paenibacillus species: Paenibacillus hongkongensis sp. nov. Mol Pathol 56, 29-35.

Thompson, J. D., Gibson, T. J., Plewniak, F., Jeanmougin, F. \& Higgins, D. G. (1997). The CLUSTAL_X windows interface: flexible strategies for multiple sequence alignment aided by quality analysis tools. Nucleic Acids Res 25, 4876-4882.

Tindall, B. J. (1990). Lipid composition of Halobacterium lacusprofundi. FEMS Microbiol Lett 66, 199-202.

Touzel, J. P., O'Donohue, M., Debeire, P., Samain, E. \& Breton, C. (2000). Thermobacillus xylanilyticus gen. nov., sp. nov., a new aerobic thermophilic xylan-degrading bacterium isolated from farm soil. Int $J$ Syst Evol Microbiol 50, 315-320.

Watanabe, K., Nagao, N., Yamamoto, S., Toda, T. \& Kurosawa, N. (2007). Thermobacillus composti sp. nov., a moderately thermophilic bacterium isolated from a composting reactor. Int J Syst Evol Microbiol 57, 1473-1477. 